\title{
魚節だしおよび者干だしの官能評価用語の収集と整理
}

\author{
有冨 菜穂子 $^{1)}$, 東 雅子 $^{1)}$, 岸 幹也 ${ }^{1)}$, 加太 希哉 ${ }^{2)}$, 國枝 里美 ${ }^{3)}$ \\ ${ }^{(1)}\left(\right.$ 株) ミッカングループ本社, ${ }^{2)}\left(\right.$ 株) ミッカン, ${ }^{3}$ 高砂香料工業 (株))
}

\section{Sensory evaluation terms for soup stocks of dried bonito and other dried fishes}

\author{
Nahoko Aritomi $^{1)}$, Miyako Azuma ${ }^{1)}$, Mikiya $\mathrm{KISHI}^{1)}$, Shizuya KabUto ${ }^{2)}$ \\ and Satomi Kunied ${ }^{3)}$ \\ ${ }^{1)}$ Mizkan Group Co., ${ }^{2)}$ Mizkan Co., Ltd, ${ }^{3)}$ TAKASAGO International Co.
}

\begin{abstract}
Dried bonito stock (katsuobusi dashi) and other dried fish stocks are important and essential ingredients for Japanese foods. We collected and selected evaluation terms for several dried fish soup stocks to represent the characteristics of their aroma and flavor. The evaluation terms were arranged in a 'flavor wheel for dried fish soup stocks' and reference standards were set for each individual term. Sensory evaluation was then performed using these evaluation terms, and the profiles of dried fish soup stocks were analyzed. The results showed that the selected evaluation terms clearly represented the general characteristics of each soup stock. In this study, we were able to develop evaluation terms suitable for the evaluation of dried fish soup stocks.
\end{abstract}

(Received 27 October 2009, Accepted 17 March 2010)

Keywords: soup stock だし汁, evaluation term 評価用語, sensory evaluation 官能評価

\section{1. 緒言}

和食に欠かすことができないものの 1 つに，㙰節を はじめとする魚節や煮干のだしがある。これらは, 魚 の種類や節の製造工程，だし汁の取り方によって，味 や香り, テクスチャー（以下，これらをまとめたもの をフレーバーと呼ぶ）が大きく変化する．その官能的 な特性を表現するには適した用語が必要である.

鰹節や鰹節だしのフレーバー特性に言及した報告と して, 川口（2005）や河野（2008）の報告がある。 川 口は「肉質的な香り」「香ばしい焙乾香」「くん煙臭」 「魚の生ぐさ臭」で鰹節の香りが構成されるとしてい る.また，河野は，鰹節だしと鶏湯を用いた日本と中 国での消費者調查の中で,「油っこさ」「生臭み」「薰 煙臭」「うま味」「渋味」「後味」という用語を使用し ている。 しかしながら，川口の報告は機器分析によっ
て測定された䚚節香気成分の中で, 特に鰹節の香りに 貢献する香気成分を決定することが目的である。した がって官能評価によるだし汁の特性を解析するために 選定した用語ではない. また, 河野の報告は一般の評 価者を対象としており，鰹節だしと鶏湯という原料や 製法が大きく異なるものに対する国際間の差を抽出す るための用語である. 先に述べたような和食に使用さ れる各種魚節だしの瀻細な違いを表現するための用語 ではない. 鰹節だしと鯖節だしのような類似しただし 汁のフレーバー特性を理解するには, より具体的で細 分化された用語が必要である.

そこで, 本研究では魚節だしおよび煮干だしのフ レーバーを表現する用語を網羅的に収集し, 整理する ことを目的とした，整理された用語によりフレーバー 特性を把握できることを検証するために, ISO11035 
（1994）を参考とした官能評価分析を実施した。得ら れた官能評価分析の結果について分散分析およびクラ スタ分析による解析を行い，魚節だしおよび劣干だし のフレーバーを客観的に捉えることができることを明 らかにした。

\section{2-1. 実験方法一使用サンプル}

評価サンプルとして鰹荒節, 鰹枯節, ムロ鯵節, 鯖 節, 宗田節, カタクチイワシの煮干 (以下煮干とす る) (以上は $2 \sim 5 \mathrm{~cm}$ 角の粗砕品), 䚫節整形時に出る 削り粉（以下 $\mathrm{G}$ 粉とする）拉よび市販の花かつお（鰹 荒節の薄削り）を用意した。サンプル 8 種類のうち 6 種類が粗砕品であったこと，また，工業的には複数の サンプルを一緒に入れてだしを取ることもあるため, 抽出方法は厚削りで用いられている方法に統一した。 具体的には各節または煮干 $33.3 \mathrm{~g}$ を $90 \pm 2^{\circ} \mathrm{C}$ に保持し た湯 $1 \mathrm{~L}$ の中に投入して蓋をし，液温を $90 \pm 2^{\circ} \mathrm{C} に て$ 30 分間保持した. 抽出しただし汁は不織布で出来た 「だしこしシート」((株) 伏高製) でろ過した後, 収 率を一定にするために水で $1 \mathrm{~L}$ にフィルアップした.

\section{2-2. 実験方法ーパネル}

用語の収集は（株）ミツカングループ本社および （株）ミッカンのつゆ・だし開発者と研究員, 高砂香 料工業（株）のフレーバーリストと研究員, 計 10 名 で行った。

官能評価は用語に対するイメージを統一する訓練を 行った（株）ミッカングループ本社および（株）ミツ カンのつゆ・だし開発者と研究員, 計 12 名で行った.

\section{2-3. 実験方法一試料の供試方法}

だし汁の提示は温麺や吸い物の契食時を想定して設 定した，通常，これらを喫食する際にはまず鼻から入 る香りを感じ，その後口に含んだときの味および鼻か ら抜ける香りを感じる，そこで，前者を想定して「香 りサンプル」, 後者を想定して「風味サンプル」を用 意した.

香りサンプルは予め $80^{\circ} \mathrm{C}$ の乾熱器で温めておいた 硬質ガラス製のワイングラスに $78 \pm 2^{\circ} \mathrm{C} に$ 温めただし 汁を $20 \mathrm{ml}$ 入れて供試した，風味サンプルは無臭であ ることを確認したディスポーザブルのプラスチック カップに $65 \sim 70^{\circ} \mathrm{C}$ のだしを $40 \mathrm{ml}$ 入れて供試した.

\section{2-4. 実験方法一評価用語の収集・整理}

評価用語の収集および整理は既往文献 (BCOJ 編, 2002，宇都宮，2007）を参考にして実施した.

用語の収集には評価サンプルとして用意した 8 種類
のだし汁を用いた，各だし汁の香りサンプルおよび風 味サンプルを 1 セットとして, 1 セットずつ各パネル に供試した．記述用紙はサンプル毎に 1 枚ずつ用意し た. 自由記述形式により各パネルの感じた香り・味・ テクスチャーなどの用語を収集した。また，(株）ミ ツカンでこれまで用いていた用語「コゲくん煙風味」 「煮干風味」「生臭い」「甘い」「はなやか」「肉質風味」 を細分化することによる収集も行った.

収集された全用語は, 同次元に羅列され，用語収集 の評価に参加したパネルに公開された．以下の基本方 針に則り, パネル間の協議による用語の整理を行った 用語体系は分かりやすいように，一般的な用語で表し た「第 1 階層 : 大分類」とより具体的な用語で表した 「第 2 階層：評価用語」の 2 階層にまとめた.

(1) 抽象的な用語, 曖昧な用語は客観的に評価でき ないため避ける

(2) ひとつのフレーバー特性に対する用語はまとめ る（重複して用語をつけない）, 類似のフレー バーはまとめて配置する

(3) パネルが同じイメージで評価できる用語にする （専門家しか分からない用語や業界用語は入れ ない)

(4) 節名で用語を説明しない

香りに関する評価用語のイメージを揃えるための標 準見本は，用語に適したに扔いを有する香料（高砂香 料工業（株）製）および食品サンプルとした．標準見 本となる香料は, パネルと複数のにおい見本の候補を 実際に嗅ぎながら，そのにおい質を討議することによ り選定した。

\section{2-5. 実験方法一官能評価}

だし汁の官能評価は，直接嗅いだ際の香りおよび飲 み込んだ際の香味やテクスチャー等のフレーバーにつ いて行った。試料には前述した香りサンプルおよび風 味サンプルを用いた，官能評価は個々のブースがつい たてで仕切られた評価室で実施した. ISO11035(1994) の手順に従い，まず標準見本を用いてパネルの用語に 対するイメージを統一した，次に，パネルの感覚疲労 を軽隇するため, 1 回の評価用語を 15 語程度まで絞 込む作業を実施した，具体的には以下(1)〜(3)の手順で 行った.

(1) 前述のパネル及び香りサンプルを用い，0〜5 までの 6 段階のカテゴリー尺度（感じない 0 , 弱い 1 , やや弱い 2 , どちらでもない 3 , やや 強い 4, 強い 5）を用いた評価を実施した. 
Table 1 Evaluation terms of dried fish soup stocks

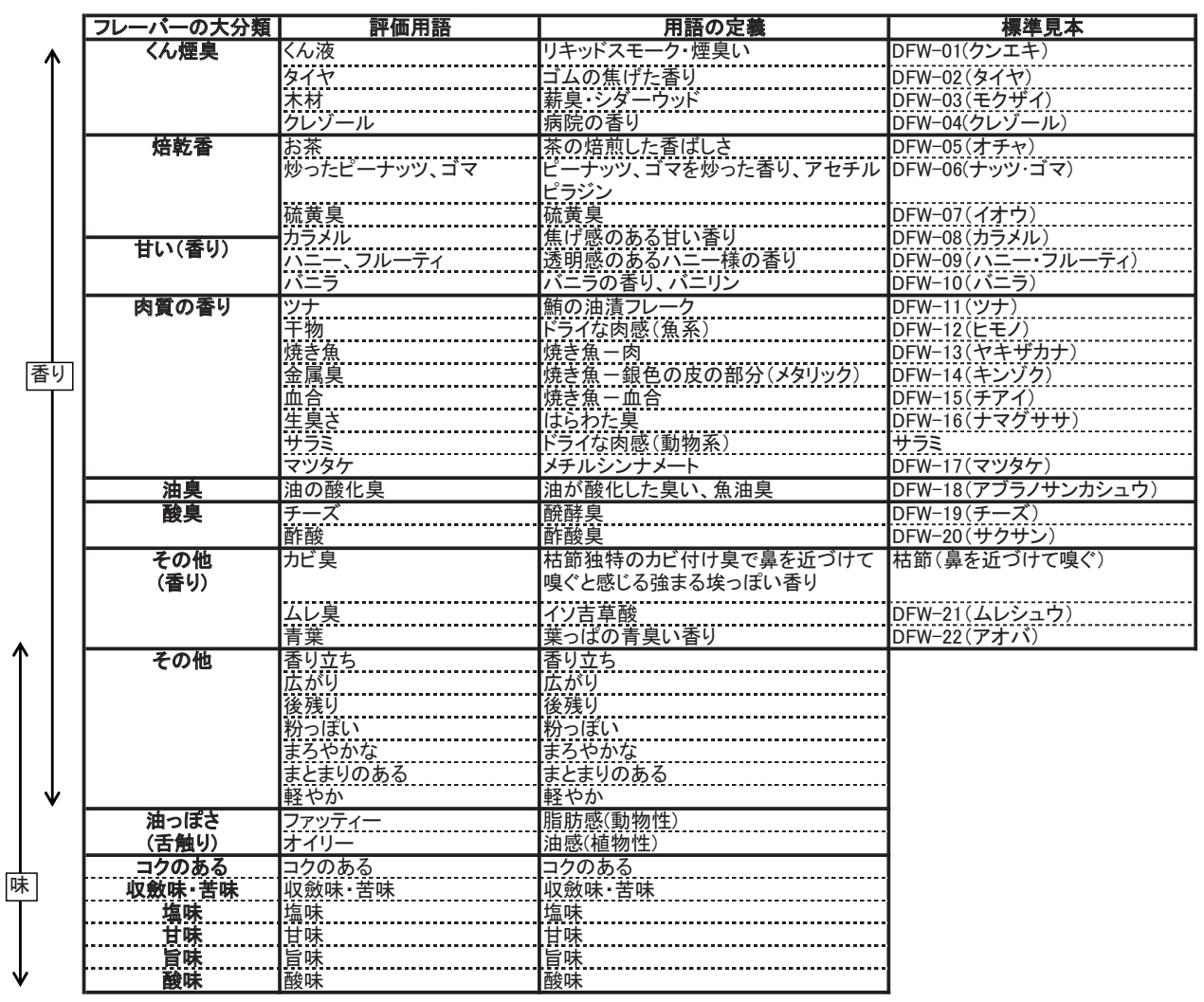

(2) 出現頻度 $F$ （弱い 1〜強い 5 にパネルが評価し た回数を全評価回数で除したもの）と強度 $I$ (感じない 0 , 弱い 1 , やや弱い 2 , どちらでも ない 3 , やや強い 4 , 強い 5 の合計を, 全評価 が 5 点だったときの点数の合計で除したもの) の数值の合計の相乗平均 (geometric mean, 以下 GM 值）を計算した. GM 值は以下の数式 で表される.

$$
(\mathrm{GM} \text { 值 })=\sqrt{F I}
$$

(3) GM 值が概ね $25 \%$ より低い用語については省 いた。また，相関の高い用語についてまとめた 後, サンプルが変わっても強度 $I$ の差がない用 語は省いた。

官能評価プロファイルを取得するため $15 \mathrm{~cm}$ の線尺 度を用いた評価を実施した。まず，絞り达まれた用語 それぞれの強度をパネル間で合わせる訓練を行った. 訓練終了後, 実際の評価を行った。 その際, 各パネル に対して 8 種類のサンプルをそれぞれ 2 回ずつランダ
ムに供試した。

分散分析およびクラスタ分析はSPSS for Windows （version $11.5 \mathrm{~J}$; SPSS 社）を用いて行った. 多重比 較はTukey 法を用い, 有意水準は両側検定で $1 \%$ 以 下とした. また，クラスタ分析には平方ユークリッド 距離によるウォード法を用いた.

\section{3-1. 実験結果-用語の収集・整理}

サンプルをパネルに供試し，フレーバー特性を自由 記述形式で収集した結果，123語の用語が収集された。 またこれまで使用してきた用語の細分化作業からは 108 語の用語を収集した。これらの用語を 2-4. に示し た基本方針に従って以下の手順により整理した。

i ) 基本方針(1)(3)(4)に従い，抽象的な用語 - 専門家 しか分からない用語・節や煮干を含む用語を除外した。

ii ) 基本方針(2)にしたがい同義の用語を一つの用語 にまとめる検討を実施した。だし汁や食品サンプルを 用いて確認しながら, パネルの討議によりイメージが 同じ用語を集約した。 また，集約はできないがイメー 


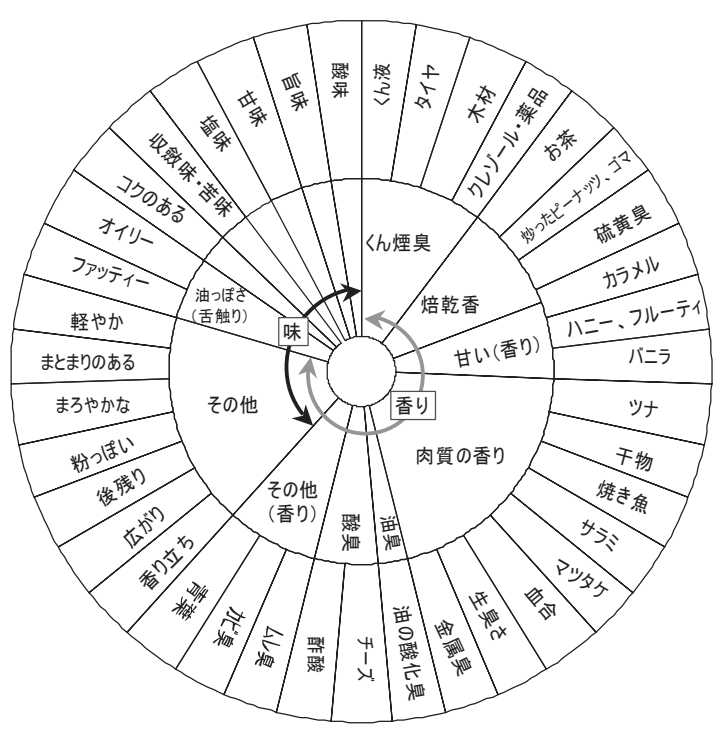

Figure 1 The Flavor Wheel of dried fish soup stocks

ジの似ている用語を把握した.

iii）香り特性の具体的イメージを共有するため, フ レーバーリストが用語に対応する香料見本の候補を選 定した，再びパネルの討議を実施し，パネルの認識が 一致する香料を標準見本として設定した.

結果として，魚節だしおよび煮干だしの風味を表す 用語として 39 の用語に整理することができた。類似
の用語をまとめて配置したところ，これらは一般的な 用語で表される 15 分類にまとめることができた。ま た，香り特性を表す用語にはイメージを共有するため の香りの標準見本を設定した（Table 1)。パネル討議 のなかで「サラミ」および「カビ臭」に関してはパネ ル全員の意見が一致する香料が設定できなかったため 食品サンプルで設定した.

用語間の関係とその分類を分かりやすく示すために 魚節だしおよび煮干だしのフレーバーホイールを作成 した (Figure 1).

\section{3-2. 実験結果-用語を用いただし汁の特性解析}

評価を行うにあたり 24 語ある香り特性を表す用語 を絞り込む作業を実施した。 それぞれに対して頻度 $I$ と強度 $F$ の相乗平均である $\mathrm{GM}$ 值を測定した。結果 を Table 2 に示す. 方法に示した手順に従い, 香りサ ンプルの GM 值と風味サンプルの GM 值が共に $25 \%$ 以下であることを目安として 6 用語を省いた。「ムレ 臭」は香りサンプルの GM 值が $25.2 \%$ でるが, 各 值を比較した結果「クレゾール・薬品」と同等である と判断し省いた。また，「血合」と「生臭さ」,「金属 臭」と「油の酸化臭」と「焼き魚」「カラメル」と 「ハニー・フルーティ」については用語間の相関係数 が 0.45 以上 $(\mathrm{p}<0.01)$ であったので集約した. さら に,「硫黄臭」,「サラミ」については標準偏差が 1 以 下とサンプル間での強度の差が無かったので用語から

Table 2 Calculation of the frequency, $F$, the relative intensity, $I$, and GM (geometric means) value of each evaluetion terms by the 8 dried fish soup stocks.

\begin{tabular}{|c|c|c|c|c|c|c|}
\hline & \multicolumn{3}{|c|}{ 香り } & \multicolumn{3}{|c|}{ 風味 } \\
\hline & 頻度 $(F)$ & 強度 $(I)$ & GM & 頻度 $(F)$ & 強度 $(I)$ & GM \\
\hline 〈ん液 & $98.1 \%$ & $62.5 \%$ & $78.3 \%$ & $97.4 \%$ & $44.6 \%$ & $65.9 \%$ \\
\hline 焼き魚 & $93.4 \%$ & $55.8 \%$ & $72.2 \%$ & $92.1 \%$ & $36.8 \%$ & $58.2 \%$ \\
\hline 木材 & $94.4 \%$ & $48.7 \%$ & $67.8 \%$ & $91.7 \%$ & $33.6 \%$ & $55.5 \%$ \\
\hline 金属臭 & $88.7 \%$ & $49.9 \%$ & $66.5 \%$ & $87.8 \%$ & $34.4 \%$ & $55.0 \%$ \\
\hline ツナ & $90.6 \%$ & $41.4 \%$ & $61.3 \%$ & $90.5 \%$ & $29.3 \%$ & $51.5 \%$ \\
\hline 干物 & $85.9 \%$ & $40.8 \%$ & $59.2 \%$ & $84.3 \%$ & $25.7 \%$ & $46.6 \%$ \\
\hline 生臭さ & $86.9 \%$ & $39.9 \%$ & $58.9 \%$ & $82.3 \%$ & $23.6 \%$ & $44.1 \%$ \\
\hline 油の酸化臭 & $84.6 \%$ & $40.2 \%$ & $58.3 \%$ & $79.2 \%$ & $26.1 \%$ & $45.4 \%$ \\
\hline 血合 & $85.4 \%$ & $39.2 \%$ & $57.8 \%$ & $85.7 \%$ & $26.5 \%$ & $47.7 \%$ \\
\hline 炒ったピーナツツ、ゴマ & $79.9 \%$ & $32.4 \%$ & $50.9 \%$ & $82.5 \%$ & $21.9 \%$ & $42.5 \%$ \\
\hline お茶 & $81.8 \%$ & $31.3 \%$ & $50.6 \%$ & $85.3 \%$ & $27.9 \%$ & $48.8 \%$ \\
\hline 硫黄 & $67.1 \%$ & $21.2 \%$ & $37.7 \%$ & $61.5 \%$ & $13.2 \%$ & $28.4 \%$ \\
\hline カビ臭 & $58.9 \%$ & $21.9 \%$ & $35.9 \%$ & $60.4 \%$ & $15.1 \%$ & $30.2 \%$ \\
\hline ハニー、フルーティ & $55.6 \%$ & $21.0 \%$ & $34.2 \%$ & $48.1 \%$ & $10.7 \%$ & $22.7 \%$ \\
\hline カラメル & $57.5 \%$ & $19.0 \%$ & $33.0 \%$ & $54.5 \%$ & $12.3 \%$ & $25.9 \%$ \\
\hline サラミ & $53.7 \%$ & $18.6 \%$ & $31.6 \%$ & $50.6 \%$ & $11.8 \%$ & $24.4 \%$ \\
\hline タイヤ & $51.9 \%$ & $16.4 \%$ & $29.2 \%$ & $51.5 \%$ & $13.3 \%$ & $26.2 \%$ \\
\hline ムレ臭 & $44.9 \%$ & $14.2 \%$ & $25.2 \%$ & $41.6 \%$ & $8.5 \%$ & $18.8 \%$ \\
\hline クレゾール・薬品 & $47.2 \%$ & $13.3 \%$ & $25.0 \%$ & $45.5 \%$ & $8.8 \%$ & $20.0 \%$ \\
\hline マツタケ & $44.9 \%$ & $12.3 \%$ & $23.5 \%$ & $44.6 \%$ & $8.0 \%$ & $18.8 \%$ \\
\hline チーズ & $39.3 \%$ & $12.2 \%$ & $21.9 \%$ & $32.5 \%$ & $5.3 \%$ & $13.1 \%$ \\
\hline バニラ & $37.4 \%$ & $12.6 \%$ & $21.7 \%$ & $25.5 \%$ & $5.4 \%$ & $11.7 \%$ \\
\hline 青葉 & $31.3 \%$ & $9.0 \%$ & $16.8 \%$ & $28.1 \%$ & $6.1 \%$ & $13.2 \%$ \\
\hline 醢酸 & $11.3 \%$ & $3.2 \%$ & $6.0 \%$ & $11.3 \%$ & $2.3 \%$ & $5.0 \%$ \\
\hline
\end{tabular}


Table 3 Summary for sensory evaluation of the 8 dried fish soup stocks.

\begin{tabular}{|c|c|c|c|c|c|c|c|c|c|c|c|c|c|}
\hline & 〈ん液 ${ }^{* *}$ & タイヤ゙* & 木材 & お茶 & $\begin{array}{l}\text { 炒ったピー } \\
\text { ナツツ、ゴ } \\
\text { マ }\end{array}$ & $\begin{array}{l}\text { カラメル. } \\
\text { ハニー、フ } \\
\text { ルーティ }\end{array}$ & ツナ** & 干物 ${ }^{* *}$ & $\begin{array}{l}\text { 生臭さ· } \\
\text { 血合 }\end{array}$ & $\begin{array}{l}\text { 金属臭· } \\
\text { 油の酸化臭· } \\
\text { 焼き魚 }\end{array}$ & 酸味 & 旨味 ${ }^{* *}$ & $\begin{array}{c}\text { 苦味- } \\
\text { 収斂味 }\end{array}$ \\
\hline 鯖節 & 7.5 abcd & 3.8 abc & 57 a & $56 . a$ & $5.2 . a$ & $4.0 \mathrm{a}$ & 6.6 abcde & 6.7 abc & 6.3 abc & 8.1 abce & 3.4 a & 6.4 abcdeg & 4.3 a \\
\hline 㕕口鯵節 & 73 abcd & $33 \mathrm{ac}$ & $56 a$ & $53 a$ & $5.2 a$ & $44 a$ & 71 acde & $67 \mathrm{abc}$ & $61 \mathrm{ab}$ & 78 abcde & $2.9 a$ & 72 abcdefg & 39 \\
\hline 宗箇節。 & 6.8 abcd & 300 ac & $54 a$ & 56 & 4.9 a & $37 \mathrm{a}$ & 6.7 abcde & $6.5 \mathrm{abc}$ & $56 \mathrm{ab}$ & 7.1 abcde & $3.5 \mathrm{a}$ & 6.5 acdefg & $40 \mathrm{a}$ \\
\hline 花莎等 & 76 abcd & $300 \mathrm{ac}$ & $58 a$ & $58 \mathrm{a}$ & $52 a$ & $47 a$ & 76 cde & 66 abc & $55 \mathrm{ab}$ & 6.7 abcde & $3.8=$ & 81 bdefg & $39 a$ \\
\hline 著羊 & $62 \mathrm{bd}$ & 3.5 abc & 50 a & $50 a$ & 55 a & $43 \mathrm{a}$ & 6.8 abcde & 71 ac & $80 \mathrm{bc}$ & $86 \mathrm{bc}$ & $2.6 \mathrm{a}$ & 74 cdefg & $44 \mathrm{a}$ \\
\hline 鰹瞏節 & 82 abc & 36 abc & 62 a & $55 a$ & $4.5 a$ & $41 \quad a$ & 56 abcd & 52 abc & $48 \mathrm{ab}$ & 6.2 abcd & $3.3 a$ & 55 abcde & $39 a$ \\
\hline 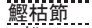 & 800-abc- & 36 abc & 66 a & 57 a & $5.2 a$ & $46-2$ & 56 abcd & 54 abc & 50 ab & 6.0 abde & $29 a$ & 6.3 acdeg & $43 a$ \\
\hline 粉 & $10.2 \mathrm{e}$ & $5.0 \mathrm{ab}$ & 6.8 a & $6.0 \mathrm{a}$ & $5.5 \mathrm{a}$ & $3.2 \mathrm{a}$ & $5.1 \mathrm{abc}$ & $5.1 \mathrm{ab}$ & $4.9 \mathrm{ab}$ & 6.9 abcde & $2.8 \mathrm{a}$ & $4.9 \mathrm{abcd}$ & $5.2 \mathrm{a}$ \\
\hline
\end{tabular}

除いた.「カビ臭」については強く感じるパネルと全 く感じないパネルに分かれたため, 評価項目から省い た. 結果として香りの 24 用語を 14 用語, 10 項目に 絞り込んだ。味に関する用語のうち『大分類：その 他』と『大分類：油っぽさ』に関わる用語および「コ クのある」については定量的に評価しづらいので省い た.「塩味」「甘味」特性はサンプル間での差が分かり づらいという意見がパネル間で一致したため省いた。 結果として, Table 3 に示した 13 項目に絞り込んだ.

「香りサンプル」により感じる香りと飲み込んだと きに感じる「風味サンプル」による香りの評価結果は, 各項目で $0.54 \sim 0.77$ の相関 $(\mathrm{p}<0.01)$ があったため, 「風味サンプル」の評価に対する平均值と分散分析結 果のみを Table 3 に示す。この結果, 「くん液」「タイ ヤ」「ツナ」「干物」「金属臭・油の酸化臭・焼き魚」 「生臭さ・血合」「旨味」は, サンプル間で有意な差が 認められた。「くん液」「タイヤ」は $\mathrm{G}$ 粉で最も強く 評価され，「金属臭・油の酸化臭・焼き魚」「生臭さ 血合」は煮干で強く評価された．「ツナ」「干物」「旨 味」は花かつお，煮干，么口鯵節で強く評価された。

評価結果がだし汁のフレーバー特性を捉えているこ とを検証するために, Table 3 の結果を用いてクラス 夕分析を実施し、サンプルを分類した。その結果, 鰹 荒節, 鰹枯節， G 粉といった鰹を原料としている節類 とその他の雑節・者干類に分かれた．花かつおは雑節 類に分類された（Figure 2).

\section{4. 考察}

ビールや清酒の例を参考にして, 魚節だしおよび煮 干だしの香味やテクスチャー, その他の官能特性を網 羅した用語を設定することを試みた。だし汁のフレー バー特性に関する用語集や網羅的に収集した報告はな かったので, 実サンプルを用いて用語の収集を行った. また，これまでに使用してきた用語を細分化すること による収集を行った。これらから具体的な用語を重複

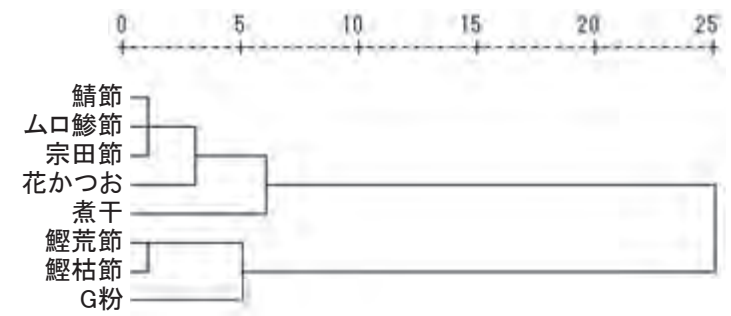

Figure 2 Classification of the 8 dried fish soup stocks using cluster analysis.

なく39の用語に整理した。用語の重複を集約する作 業ではパネルがだし汁のフレーバー特性として個々に 弁別できるかどうかを基準とした，また，類似の用語 はまとめて一般的な用語による大分類を設定した。 大 分類は一般パネルの評価に使用したり, 専門パネルの 評価によるだし汁のフレーバー特性を一般消費者に伝 えたりする際に用いることを想定している.

今回,「サラミ」および「カビ臭」に関してはパネ ル全員の意見が一致する香料が設定できなかったため 食品サンプルで設定した。「サラミ」は食品サンプル でイメージを揃えることができたが,「カビ臭」は不 安定な香りであり, 標準見本である「枯節」も窒素充 填下から解放すると保管中に香りが消失してしまう現 象が確認された.「カビ臭」は魚節のかび付け臭を想 定しており，用語の整理に携わったパネルのなかでは イメージが一致したため用語の一つとして採用した. しかしながら, 用語の集約の際に参加したパネルの中 では訓練しても「カビ臭」を感じられないパネルがい たため評価項目から省かざるを得なかった。「カビ臭」 の標準見本を香料などで設定することが用語イメージ の統一のために必要であり今後の課題である.

整理した用語でだし特性が表現できることを確認す るためにISO11035を参考にした評価を行った。 Table 3 に示した結果より「鰹節類（鰹荒節，鰹枯節， G 粉)」のだし汁は「くん液」「木材」といった『大分 
類：〈ん煙臭』が特徵的であった。一方で雑節類（鯖 節，ムロ鯵節，宗田節）および花かつおは「ツナ」 「物」「生臭さ・血合」「金属臭・油の酸化臭・焼き 魚」といった『大分類：肉質の香り』と「旨味」が強 く評価された，煮干は「生臭さ・血合」「金属臭・油 の酸化臭・焼き魚」が雑節類よりもさらに強いことが 特徴であった.

これらの結果と各種だしに対する一般的な解説を比 較した。“クセが少なく, 上品な味と香り”を特徵と する鰹節類，鰹節と比較すると“濃厚”で “旨味の強 い”だしがとれる雑節類，さらに，“燻製にかけてお らず魚のくせが強い”煮干だし（柴田書店, 2006）と いった特性を把握できることが示唆された。鰹荒節の 薄削りである花かつおについては「ッナ」「旨味」の 強い雑節類に分類された．花かつおは薄削りであるた め 10 分以内の短時間でだしを抽出するのが一般的で ある. 本研究では厚削りの抽出法である 30 分間の抽 出に統一して行ったため雑風味が抽出されたと考えら れた。

また，用語の収集の際には用いられなかった鮁荒節 （薄削り）だしおよび焼あごだしについても，集約さ れた用語で評価を実施した。その結果，鮁荒節（薄削 り）は鰹荒節（粗砕）と比較して「ツナ」「カラメ ル・ハニー, フルーティ」「旨味」が強く「生臭さ・ 血合」が弱く，また，焼あごは煮干と比較すると「生 臭さ・血合」「旨味」が弱い一方で「木材」が強く, 鰹荒節よりは「金属臭・油の酸化臭・焼き魚」が強い と評価され, 特徵の違いの妥当性を確認することがで きた

本試験では大きな特徵を捉える方法である ISO11035を参照とした方法を用いたため, 出現頻度 が少なく強度の小さい用語を省いているが, 前述のと おり，今回整理した用語を用いることで異なる節から 抽出しただし汁の特性を評価できることが示された。
同時に，魚節だしや煮干だしの評価を初めて実施する パネルでも，用語と標準見本を用いて訓練することに より，適切にだし汁のフレーバー特性を捉えられるこ とが示された. しかし，今後さらに多くの種類のだし 汁を評価するにあたっては，省いた用語を追加する必 要があるかもしれない，また，省いた用語の強弱を特 徵とするようなだし汁を開発したい場合は，その用語 を追加して評価に使用していきたい. 今後は用語間の 関係や用語と成分や消費者嗜好との関連を把握する等, 用語の活用法を模索していきたい.

\section{5. 引用文献}

1）BCOJ 編（2002）12. 香味用語法および標準見本, 14. フレーバーホイール, 『BCOJ 官能評価法』, 日本醸造協会, 東京都

2) International Organization for Standardization (1994) Sensory analysis-Identification and selection of descriptors for establishing a sensory profile by a multidimensional approach, ISO11035, International Organization for Standardization, Geneva, Switzerland

3）川口宏和（2005）かつ扮節フレーバーの生成と劣 化，『日本人はなぜかつ扔を食べてきたのか』，味 の素食の文化センター, 東京都, pp77-88

4）河野一世（2008）かつ扮節とかつ擳だしに関す る調理科学的・食文化的考察 3-4 かつ擳だし に対する日本人と中国人の嗜好の比較, 日本調理 科学会誌, 41 (1) $2-10$

5）柴田書店編（2006）『だしの基本と日本料理』，柴 田書店, 東京都, pp16-19, pp82-83

6）宇都宮仁（2007）清酒の官能評価にかかわるにお い・かおりについて，におい・かおり環境学会誌 38 (5), 352-360 